\title{
Approaching climate change to society from the media: formative elements in Spanish digital newspapers
}

\author{
Sonia Parratt Fernández \\ Montse Mera Fernández \\ Paloma Abejón Mendoza
}

${ }^{I}$ Complutense University of Madrid, Madrid, Spain.

"I Complutense University of Madrid, Madrid, Spain.

III Complutense University of Madrid, Madrid, Spain.

\begin{abstract}
On the basis of media's responsibility with regard of the environment, this study focuses on a new aspect within the research about media coverage of climate change: the presence of elements that would contribute to make this phenomenon known and understood, and to guide readers on how to individually tackle it. The method used was content analysis of digital editions of the most widely read general information newspapers in 2017. Findings suggest that newspapers hardly include simple explanations about climate change; they contextualize the phenomenon addressing its causes and effects, but these still prevail over the former; they provide citizens scarce guidance on how to combat it; and they make limited use of visual resources. These data provide an interesting starting point for future studies on the effectiveness of formative elements to encourage readers' involvement.
\end{abstract}

Keywords: Climate change; media; environmental journalism; environmental education; formative elements; newspapers; Spain

São Paulo. Vol. 24, 2021

Original Article

DOI: http://dx.doi.org/10.1590/1809-4422asoc20200186vu2021L2AO 


\section{Introduction}

\subsection{Perception and knowledge of a global problem}

Although climate variations have been detected over some time, in general, citizens see climate change as a complex global issue, as shown by studies on public perception of global warming (BORD et al., 1998; BRULLE et al., 2012; MEIRA, 2013; LEÓN, 2013; LEE et al., 2015; SMITH; MAYER, 2018). Currently, 67\% of people surveyed from 26 countries consider it the most serious international problem, a figure that reaches $71 \%$ in Europe and 81\% in Spain (PEW RESEARCH CENTER, 2019, p. 5 and 8).

Heras (2008) sees a certain contradiction in the Spanish data because "the fact that a problem is serious on a global scale does not mean that it occurs far away, but that it affects all places (...) [and yet] climate change is perceived as a problem that (...) does not affect us personally" (p. 209). Forty-seven percent of Spaniards point to national governments and the European Union as the main bodies responsible for solving it (EUROPEAN COMMISSION, 2017, p. 26), and the Intergovernmental Panel on Climate Change (IPCC, 2018), which gives priority to the need for ambitious and well-designed public policies, is along the same lines. But it also reminds society of the need to take steps "through behavioral and lifestyle changes" (IPCC, 2018, p. 161), while the European Environment Agency (EEA, 2015, p. 57) insists that "we all have a role to play at national, local, and individual levels".

On the other hand, ARIAS and ROSALES (2019) maintain that the understanding, dimensions and possible ways of addressing the climate phenomenon are constantly debated from various knowledge areas, giving rise to multiple discourses "which, on many occasions, contribute to clarifying the complexity of the problem but, on other occasions, have served to distract attention and to form a mistaken conception and understanding of its causes and consequences (...)". In this sense, studies carried out some time ago observed that most people knew, thanks mainly to the media, the term "global warming", although they were not able to explain what it was exactly and had a confused perception about its nature, causes, and consequences (BORD et al., 2003). A decade ago 90.7\% of the Spanish population claimed to have heard or read something about climate change, but $41 \%$ only partly understood the meaning of the term and $10.4 \%$ said they did not understand it (BBVA FOUNDATION, 2008, p. 8). They also seemed to know its causes, although with some confusion (p. 9), and a relative majority said they did not have enough information to act on it (p. 30). In 2011 only one third of Spaniards said they felt very or well informed about climate change in general (33.5\%) about its causes $(31.3 \%)$ and about its consequences (31.3\%) (MEIRA, 2013, p. 74). 


\subsection{Justification and objectives}

Research on climate change communication focuses mainly on how much, where, who, how often, and from what approach the problem is covered. Information on causes, consequences, and solutions, as well as the use of visual resources in the media has been, to a greater or lesser extent, the subject of partial studies. But these aspects have not been addressed together, not considering what links them, their educational capacity, which is where the novelty of this work presented here lies. In addition, the studies carried out are mostly diachronic analyses of the evolution of coverage over periods of time, or research that put the focus on key moments, such as great world summits, but not on continuous daily coverage, something that would contribute to a more rigorous study.

This research is based on the premise that even within the complexity of the climate problem, public policies play a fundamental role in the search for solutions, but that the need to bring the problem closer to society should not be forgotten either. In this sense, the media has a social and educational function, in addition to that of a watchdog. Media coverage of climate change has been analyzed from various perspectives, as noted above, and our purpose is to complete these analyses and find out what different formative elements present have within the information published in Spanish newspapers. That is to say, those elements that, from the scientific literature, we understand not only contribute to make the existence of climate change known, but also help understand it and guide the reader on how to act. (How the reader perceives them and their capacity to provoke "mobilizing" activities would be part of another research). As such, we will try to answer the following questions:

Q 1. Do the analyzed newspapers include definitions or explanations of climate change in the information they publish?

Q 2. Do they contextualize the problem by communicating its causes and effects?

Q 3. Do they offer recommendations or guidelines on how to mitigate and/or adapt to the effects of climate change? To whom is that information directed?

Q 4. Do they make use of practical visual resources to convey these guidelines?

Q 5. Are there significant differences between the newspapers in terms of the presence of formative elements?

Once the object of study and the objectives and justification of the importance of the research have been introduced, the following sections are dedicated to: a review of the scientific literature on the subject, the aspects of it that will be analyzed, the methodology used, a presentation of the results obtained, discussion, and finally, bibliographic references. 


\section{Literature review}

\subsection{Bringing climate change closer to society}

Europeans point to the media as their main source of information on climate change (EUROPEAN COMMISSION, 2017, p. 7), whose basic function of providing news, information and entertainment is challenged by advocates who also shape perceptions and ideas, raise awareness, construct meaning, influence and educate audiences (MASTERNMAN, 1993). This is especially true for issues on which there is social consensus, such as the need to care for the planet. Environmental education begins in childhood within the family and develops in the school environment, but it is also acquired outside of educational institutions and largely through the media (PARRATT, 2014). In this regard, Fernandez-Reyes (2011) makes the following reflection, which we take as a point of reference for our study:

In the debate on whether the formative or educational function is proper in Environmental Journalism, I prefer that the formative function is included in the informative function. Within the debate, I place myself in an intermediate position, proposing that we are not educators, but within the journalistic exercise, the information has the formative element as a basic function, an intrinsic tool that enriches the journalistic story. Information plays the central role, which is supported by training as an opportunity to improve the discussion. Formation, therefore, is part of the informative process.

Opinions about the media's capacity to modify behavior are quite different, partly because such modification is part of a complex process in which other factors intervene besides the media and environmental education. However, there is greater consensus that the media are important contributors to public understanding of the problem (BOYKOFF; ROBERTS, 2007, p. 1) and, although their political interests often override the need to raise environmental awareness (WHITE et al., 2013), they can play a critical role in raising social awareness (ARCILA et al., 2015). They are not environmental educators in a strict sense, but undoubtedly "environmental journalistic rigor contributes to social education" (CERRILLO, 2008, p. 198). In that sense, Teso et al. (2018) advocate for "journalism in transition, with sustainability as the axis of reference, as a social function of the media and as a legitimate requirement for society" (p. 229).

The above considerations led us to wonder to what extent the press, when reporting on climate change, include the fundamental concepts and knowledge in its coverage that, according to Heras $(2008$, p. 12; 2018, p. 8), is based on the perceptions of experts and should be the communicative focus. In summary, it points to the following key aspects:

\footnotetext{
Raise awareness of the causes of climate change which are necessary to understand the roots of the problem.
}

- $\quad$ Publicize the consequences that have a more realistic perception of its 
risks and the threats it represents.

Present the solutions to stop climate change as a depressing issue with no way out and to start conceiving it as a social challenge that can be acted upon.

Link climate change with the elements in daily life so that the causes, consequences, and solutions translate from the greater global data into tangible daily life.

On the other hand, media messages are full of technicalities and explanations that are not appropriate for the common public and this is why one of the principle challenges facing climate change communication is to translate scientific language into a common language (DÍAZ-NOSTY, 2017, p. 136) with practical and guiding options (JACOBI; DE ASSIS, 2016). To achieve this, Rowan (2003, p. 408) calls for the use of effective resources such as the inclusion of definitions containing simple words and short phrases, and graphics and images (p. 408). These contributions, together with those mentioned above by Heras $(2008,2018)$, will be called "formative elements", which are detailed below.

\subsection{Causes, effects and solutions}

Research carried out in Spain has detected in the press a greater presence of information on the consequences of climate change than on possible solutions and the causes (MEIRA et al., 2013; DE RUEDA, 2014; LOPERA; MORENO, 2014a; QUESADA et al., 2015; FERNÁNDEZ-REYES, 2018). Reporting little on the latter (in which the humans have the leading role) and on the ways in which the individual person can contribute to mitigation and adaptation helps make the problem perceived as something distant from one's personal environment (PARRATT, 2009; NOGUERA, 2013; QUESADA et al., 2015; FERNÁNDEZ-REYES et al., 2017). PÉREZ and PERALES (2011) and NORGAARD (2018) propose that the media should give more visibility to the possibilities of public contribution, since when reporting on possible solutions, they usually refer to what governments and industry should do (something logical considering their responsibility and also the media's role as watchdogs). In media coverage, the analyses that have been made of the presence of solutions do not distinguish between one and the other, so making this clear is one of the purposes of our study.

Heras (2008) delves into the above and, while admitting that understanding the phenomenon is not easy because its causes and consequences are broad and complex, he maintains that the knowledge necessary goes far beyond mere recognition and understanding: "It is necessary to have practical information and useful criteria to make new choices, both personally and collectively" (p. 203 and 208). This way of communicating would be what is known as service journalism, whose origins date back to the 1970s and which today has the better tools thanks to digital formats. Meneses and Martín (2015) point out the characteristics of this journalism that incorporate the scientific knowledge inherent to environmental information into the flow of information because, in their opinion, part of the media's responsibility in democratic societies is precisely to help citizens understand and get involved in something. 


\subsection{Visual resources with practical information}

The importance of visual resources (photographs, computer graphics and, increasingly, videos) as a support for news to convey messages, capture the attention of readers in a way more similar to interpersonal communication and, ultimately, as indicators of information quality, has been pointed out by several authors (among others, KOLLMUSS; AGYEMAN, 2002; SMITH; JOFFE, 2009; DEL OLMO; PARRATT, 2011; OLAYIWOLA, 2015). For Lopera and Moreno (2014b), these accompaniments have the capacity to overcome certain educational and cognitive barriers as well as reach large audiences. O'Neill and Nicholson-Cole (2009), for example, observed how photographs showing large-scale climate change impacts can be frightening, depressing, and lead to seeing the problem as distant, while those that clearly show concrete and accessible actions that people can take, lead to greater personal motivation.

A review of international work over the past two decades reveals that photographs accompanying news stories on global warming show identifiable people (mostly politicians, but also celebrities, scientists, citizens, and business leaders), the causes of the phenomenon (especially polluting chimneys) and its impacts, as well as graphic or scientific representations of the problem (O'NEILL; SMITH, 2014). In Spain, the few studies that have been done on this do not analyze graphic resources as a tool for providing service information, i.e., guidelines for practical use. In general, they note a low presence of photographs, which mostly show images of ice, snow, or glaciers. They also reveal that the possibilities offered by graphic design and computer animation are underused, but can make a subject more visible with a high degree of abstraction, such as climate change, and that when used, they mainly show the geographical distribution of data (LOPERA; MORENO, 2014b; ERVITI, 2013).

\section{Method}

The method used for the field work was quantitative content analysis and descriptive statistics. This is the most appropriate method for what the study proposes, which is to detect the presence of elements considered formative by the scientific literature (to determine whether these elements that promote greater involvement of the reader merit further research and, therefore, a different methodology). The body of analysis comes from the digital editions of the three largest Spanish newspapers (AIMC, 2017, p. 8), El País, El Mundo and ABC. Because this study does not intend to observe the evolution of coverage (as has already been done in other research) and because of the greater rigor it brings by focusing not only on the dates of international events but also on longer time periods, a limit of twelve full months was established for our study, from January 1 to December 31, 2017.

As for the selection of the analysis units, three codifiers detected through the MyNews search tool detected all texts containing three terms that, while not have the same scientific meaning, are most used when discussing climate change in non-specialized environments. The terms were "climate change", "global warming" and "greenhouse effect". 
Heras's $(2008,2018)$ and Rowan's (2003) contributions noted above served as the basis for determining the variables of the content analysis. Therefore, texts containing definitions or explanations of climate change were identified and codified as those that contextualized the phenomenon by explaining its causes and/or effects, those that offered guidelines or recommendations for mitigating or adapting to climate change, and within these, those directed at the reader were separated from those directed at governments and/or businesses. Noted also were if these guidelines appeared within the text or whether they were located outside by means of visual resources such as boxes, photographs, videos, and computer graphics.

Once coding was completed and errors corrected, 1,532 units were extracted, of which 1,169 were valid after discarding 363 in which climate change was not the central theme of the text but was simply mentioned. To test the reliability of the coding, a comparison of $20 \%$ of the units was carried out giving a result of a reliability coefficient of $86 \%$ (a figure higher than the $80 \%$ minimum required by the Holsti formula). The data extracted from the total of the final sample $(n=1,169)$ were recorded in an Excel sheet and later transferred to the SPSS program for statistical data processing and obtaining contingency tables with chi-square tests.

\section{Results}

As noted, the results of the content analysis of the selected journals yielded a total of 1,169 texts reporting on climate change. Table 1 shows a total of 12 coded variables which will be detailed separately later.

Table 1 - Frequency of analyzed variables

\begin{tabular}{|l|l|l|}
\hline Publication / Newspaper & Frequency & Percentage \\
\hline El País & 545 & 46,6 \\
\hline El Mundo & 238 & 20,4 \\
\hline$A B C$ & 386 & 33,0 \\
\hline Total & $\mathbf{1 1 6 9}$ & $\mathbf{1 0 0 , 0}$ \\
\hline Definitions and/or descriptions & Frequency & Percentage \\
\hline Yes & 16 & 1,37 \\
\hline No & 1153 & 98,63 \\
\hline Total & $\mathbf{1 1 6 9}$ & $\mathbf{1 0 0 , 0}$ \\
\hline Causes & Frequency & Percentage \\
\hline Yes & 363 & 31,05 \\
\hline No & 806 & 68,95 \\
\hline Total & $\mathbf{1 1 6 9}$ & $\mathbf{1 0 0 , 0}$ \\
\hline Consequences & Frequency & Percentage \\
\hline
\end{tabular}




\begin{tabular}{|c|c|c|}
\hline Yes & 567 & 48,59 \\
\hline No & 602 & 51,41 \\
\hline Total & 1169 & 100,0 \\
\hline Guidelines & Frequency & Percentage \\
\hline Yes & 480 & 41,06 \\
\hline No & 689 & 58,94 \\
\hline Total & 1169 & 100,0 \\
\hline $\begin{array}{l}\text { Recommendations to industry and/or govern- } \\
\text { ment }\end{array}$ & Frequency & Percentage \\
\hline Yes & 369 & 31,65 \\
\hline No & 780 & 68,35 \\
\hline Total & 1169 & 100,0 \\
\hline Readers guidelines & Frequency & Percentage \\
\hline Yes & 110 & 9,41 \\
\hline No & 1059 & 90,59 \\
\hline Total & 1169 & 100,0 \\
\hline In-text guidelines to readers & Frequency & Percentage \\
\hline Yes & 888 & 76 \\
\hline No & 287 & 24 \\
\hline Total & 1169 & 100,0 \\
\hline Charts & Frequency & Percentage \\
\hline Yes & 82 & 7 \\
\hline No & 1087 & 93 \\
\hline Total & 1169 & 100,0 \\
\hline Photographs & Frequency & Percentage \\
\hline Yes & 94 & 8 \\
\hline No & 1075 & 92 \\
\hline Total & 1169 & 100,0 \\
\hline Graphs & Frequency & Percentage \\
\hline Yes & 40 & 4 \\
\hline No & 1129 & 96 \\
\hline Total & 1169 & 100,0 \\
\hline Video & Frequency & Percentage \\
\hline Yes & 58 & 5 \\
\hline No & 1111 & 95 \\
\hline Total & 1169 & 100,0 \\
\hline
\end{tabular}

Source: Parratt, Mera and Abejón, 2019

Of the 1,169 texts, only $1.37 \%$ include definitions or explanations of the concept 
of climate change (Q.1); its causes are discussed in slightly less than one-third (31.05\%), and almost one-half (48.59\%) refer to the consequences (Q.2) (Figure 1).

Figure 1 - Texts containing explanations, causes and consequences of climate change

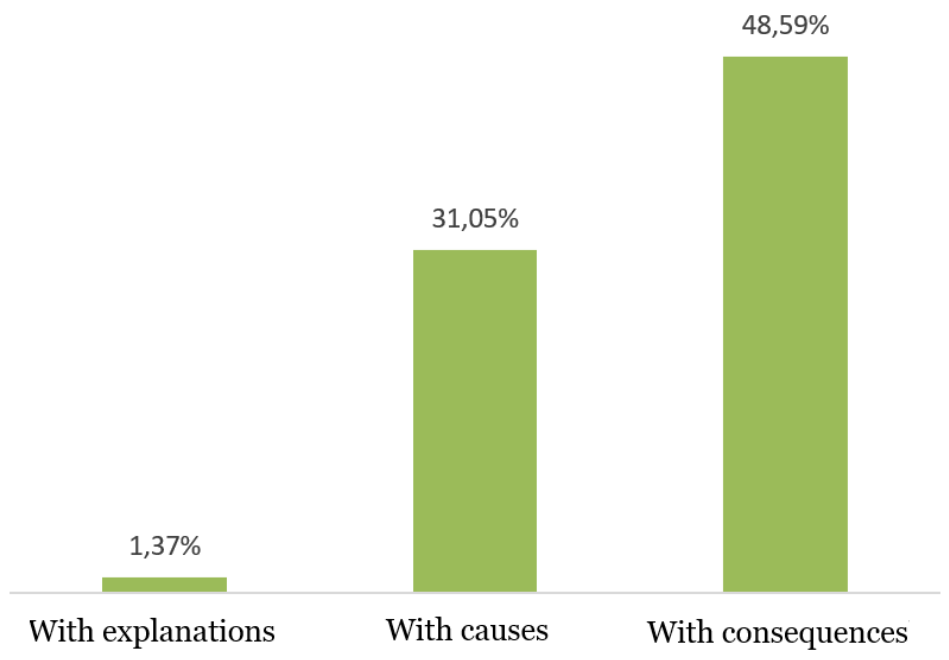

Source: Parratt, Mera and Abejón, 2019.

Regarding whether the texts include recommendations or guidelines for mitigating or adapting to the effects of global warming (Q.3), it can be seen that $41.06 \%$ do so, although only $9.41 \%$ of these are addressed to the citizen, as opposed to nearly a third (31.65\%) which are directed towards companies and/or governments (Figure 2). 


\section{Figure 2 - Texts containing guidelines or calls to action on climate change}

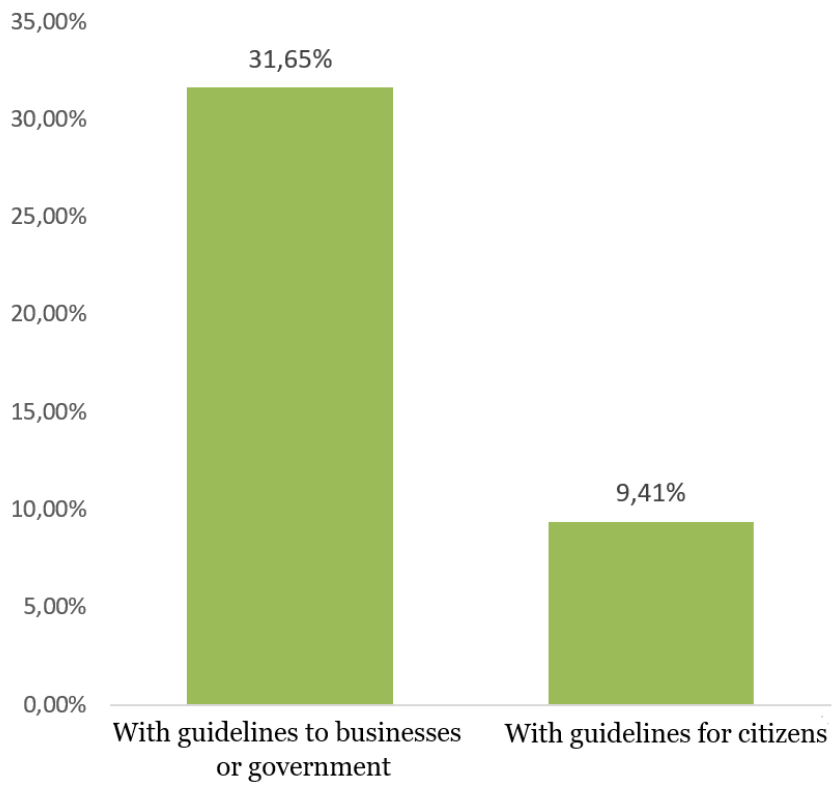

Source: Parratt, Mera and Abejón, 2019.

Another aspect investigated was to what extent the journals make use of practical visual resources to convey guidelines or recommendations to the reader (Q.4). The results indicate that more than three-quarters of the guidelines (76\%) were integrated into the main text and the remaining (24\%) were offered through visual resources, such as in boxes outside the main text $(7 \%)$, photographs $(8 \%)$, videos $(5 \%)$ and computer graphics (4\%) (Figure 3). 
Figure 3 - Placement of visual resources

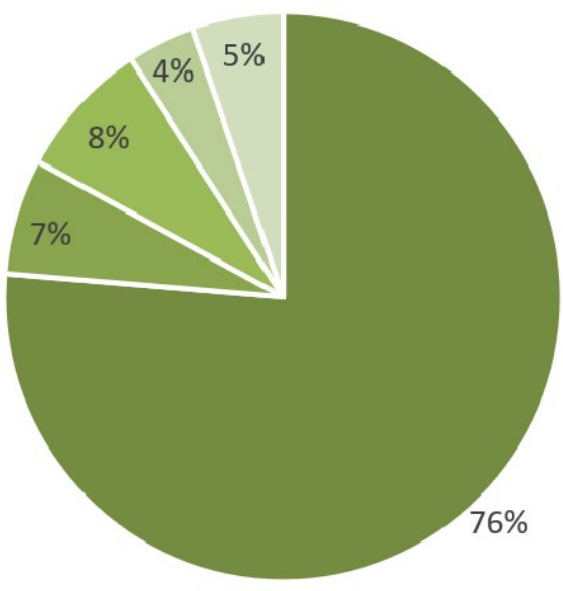

- Inside text

- Outside text

- Photographs

Infographics

Videos

Source: Parratt, Mera and Abejón, 2019.

When comparing the presence of the different formative elements analyzed, the press prioritizes information on the consequences of the climate phenomenon (48.9\%), followed by causes (31\%) and visual resources $(24 \%)$. Far behind are recommendations addressed to citizens $(9.41 \%)$ and, finally, least are the definitions or explanations of the term "climate change", which have a minimal presence $(1.37 \%)$.

Significantly, only six of the 1,169 identified texts include definitions or explanations of the term and information on causes and consequences. Of these, only one includes guidance for the reader, and not shown through visual resources, but is within the text.

Finally, an attempt was made to determine whether there are significant differences between the journals under study and the presence of formative elements analyzed (Q.5). The graph (Figure 4) shows similar figures in all three regarding the inclusion of definitions and/or explanations of the concept. The chi-square test indicates that any differences are not significant $\left(x^{2}(2)=3.67 ; \mathrm{p}>0.05\right)$. Regarding the causes, their presence is slightly higher in the conservative monarchical journal ABC $(x 2(2)=52.79 ; \mathrm{p}<0.01)$. Also significant are the differences detected in the presence of information about consequences $(\mathrm{x} 2(2)=28.85 ; \mathrm{p}<0.01)$, which is higher in the center-left newspaper El País than in $\mathrm{ABC}$ and, to a greater extent, than in the center-right newspaper El Mundo. The same occurs with the presence of reader orientations $(x 2(2)=32.05 ; \mathrm{p}<0.01)$, which are superior in El País than in El Mundo and ABC. That is, ABC is more attentive to causes, while El País and El Mundo are the same with consequences. However, El País offers more guidelines to the reader than the other two. 
Figure 4. Texts that contain explanations, causes, consequences and guidance to the reader with respect to the total number of texts

Explanation $\square$ Causes $\square$ Consequences $\square$ Guidance

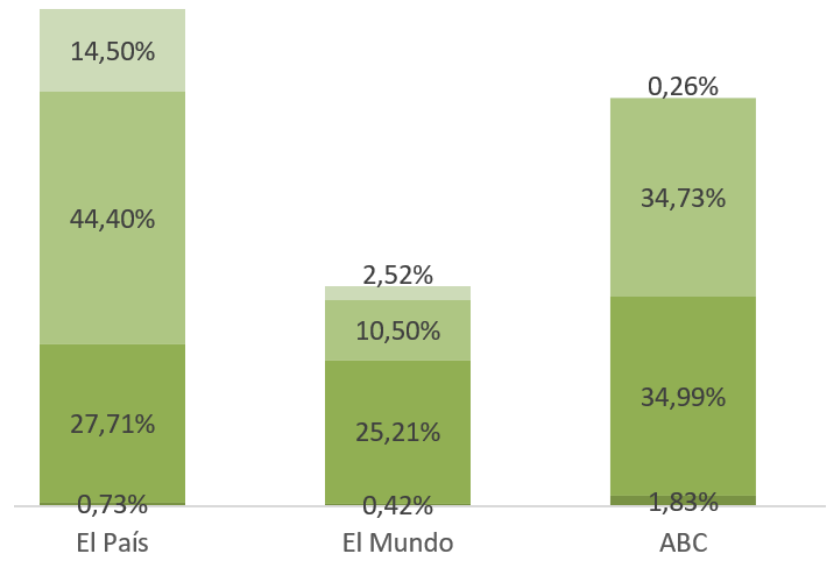

Source: Parratt, Mera and Abejón, 2019.

\section{Discussion}

As mentioned earlier, most people today know that climate change exists because they have heard about it mainly through the media, but this does not necessarily mean that they are able to clearly explain what it is. Something apparently as simple as "the inclusion of definitions containing simple words and short phrases" (ROWAN, 2003, p. $408)$ is practically non-existent $(1.37 \%)$ in the texts that deal with global warming in the Spanish newspapers analyzed, and furthermore, its presence is practically the same as those earlier identified in studies from 2006 and 2011 in the same newspapers (LEÓN; DE LARA, 2013, p. 102). Since this is a recurrent topic, it could be that journalists take for granted that their readers know what it is and do not consider the need to define or explain the meaning of the concept in a simple way when writing their texts.

The inclusion of scientific contextualization improves the understanding of complex processes and the relationship of specific facts to general, long-term situations (KUA et al. 2004, p. 320). In the case of climate change, and from the educational point of view, such inclusion would help the public to better understand the nature of the phenomenon by explaining what causes it and what its effects are and may be. The coverage of environmental phenomena, which Kua et al. have described as often superficial and out of context, seems to have improved in the case of global warming: our study reveals that the presence of explanations for the causes $(31.05 \%)$ and consequences $(48.59 \%)$ has increased with respect to those detected more than a decade ago by León and De Lara 
(2013, p. 102), who concluded that most of the information omitted both the explanation of the former (13.8\%) and the latter (20.2\%).

But there are some aspects that can still be improved. Our results indicate that the Spanish press continues to prioritize the consequences of climate change over its causes, which contradicts Meira et al. (2013), who observed that the association of the problem with its consequences were reduced in three consecutive investigations, while the opposite had occurred with the causes. It is, however, in line with previous work (MEIRA et al., 2013; DE RUEDA, 2014; LOPERA; MORENO, 2014a; QUESADA et al., 2015). In this regard, Meira et al. (2013) found that the first thoughts or images that come to people's minds are its effects when they hear about climate change: melting of polar ice and glaciers, or heat (p. 28). The authors believe that this could be precisely due to greater information and a better understanding of the consequences rather than the causes or solutions, a greater "emotional weight" of the former, and a self-image of "affected" rather than as a causal agent or actor capable of contributing, at least in part, to solving the problem (p. 30).

Reporting less on causes than on consequences increases the perception of it as a relevant problem and may be more appealing to audiences, but it has also been shown to reduce the sense that one can do something about it (O'NEILL et al., 2013; LOPERA; MORENO, 2014a) and therefore may be helping readers think about climate change as a major problem that has little to do with them as individuals. As mentioned above, Spain ranks tenth in Europe in terms of feelings of personal responsibility for global warming and sixteenth in terms of the idea that one can achieve some change in their behavior (POORTINGA et al., 2018, p. 10), and nearly a third of its citizens believe that one cannot solve it, but only contribute to it.

Moreover, the fact that $41.03 \%$ of the texts offer recommendations, calls for attention and guidelines to combat climate change would be, from the outset, what Rogener and Wormer (2015) consider to be one of the criteria that characterize good environmental journalism, which is not limited to describing problems but also includes potential solutions and courses of action. However, the fact that only $9.41 \%$ of the recommendations are addressed to citizens could, once again, be promoting the image of a problem whose responsibility is something completely alien.

Boykoff and Roberts (2007, p. 34) offer an interesting reflection on this subject. They argue that the media depend on large product advertisers for their survival and that to promote real awareness of climate change, they would have to repeatedly demand revolutionary changes in society that would greatly reduce the consumption of the advertisers' products (p. 34). However, it would be necessary to specify if this is also happening today in Spain and if there are, in addition, other reasons that could lead journalists to ignore these recommendations in their reports.

Our research has also sought to determine the ways in which the guidelines or recommendations are conveyed, particularly by using practical visual resources as a training element. As noted, most of the recommendations are integrated into the main text of the story and only a quarter of the text is done through boxes outside the main text as 
photographs, computer graphics and videos.

This confirms that aside from the limited use of iconographic elements as well as graphic design and computer animation resources for informative and explanatory purposes (LOPERA; MORENO, 2014b; ERVITI, 2013), adds to its low use when addressing the reader for more educational purposes.

As for a comparison between the three newspapers, although there are some significant differences between them, we cannot say that any one of them surpasses the others in terms of the presence of formative elements as a whole. The fact that the newspaper $E l$ País uses more visual resources than $\mathrm{El}$ Mundo and $\mathrm{ABC}$ could denote a greater concern for bringing the information closer in an attractive and close way, but its high attention to the consequences with respect to the other two indicates that it is still overly-focused on dramatic aspects of the topic.

To summarize, this work has dealt with detecting and analyzing the presence of elements that, from the scientific literature, we call 'formative' with respect to climate change. The results obtained lead us to suggest that the newspapers under study could take more advantage of their potential in regard to their social and educational responsibility in environmental matters. If we also consider that they are digital versions with the possibility of including infographics and interactive elements capable of attracting their readers' attention, this wasted potential is even greater. In short, the analyzed publications can contribute to raising the knowledge and understanding of the problem to help reverse the predominance of what Fernandez-Reyes et al. (2015) describe as the dominant media discourse "on what happens or could happen in the face of what is done or could be done" (p.136). How readers perceive information that contains more formative elements and the possible capacity of these elements to modify attitudes and actions, both in Spain and in other countries, is a question on which future research should focus in order to complete what has been analyzed here.

\section{Acknowledgments}

This article has been partially funded by the project Santander - Universidad Complutense de Madrid (PR108/20-21).

\section{References}

AEMA - AGENCIA EUROPEA DE MEDIO AMBIENTE. Señales de la AEMA. Vivir en un clima cambiante. Copenhagen: AEMA, 2015, p. 57. Available at: < https://www.eea.europa.eu/ es/publications/senales-de-la-aema-2015>. Accessed: 9 January 2019.

AIMC - ASOCIACIÓN PARA LA INVESTIGACIÓN EN MEDIOS DE COMUNICACIÓN. Resumen general de resultados EGM. Febrero a noviembre 2017: report. Madrid, 2017. Available at:<https://cutt.ly/UeCddDi $>$. Accedido: 9 January 2019.

ARIAS, M.C.; ROSALES, S. Educación ambiental y comunicación del cambio climático. Una perspectiva desde el análisis del discurso. Revista Mexicana de Investigación Educativa, México, v. 24, n. 80, p. 247-269, marzo 2019. Available at: <https://cutt.ly/dfzVeiz >. Accessed: 18 
January 2019.

ARCILA, C.; FREYLE, J.; MERCADO, M. De la Cumbre de Nairobi (2006) a Copenhague (2009): cobertura del cambio climático en medios digitales en español. Cuadernos.info, Santiago de Chile, v. 37, p. 107-119, 2015. Available at:<https://cutt.ly/1eJMhvt>. Accessed: 18 January 2019.

BLANCO, B.; QUESADA, M.; TERUEL, L. Entre Kioto y Durban. Posición editorial de los medios de referencia ante el cambio climático. Revista Latina de Comunicación Social, La Laguna, v. 68, p. 420-435, 2013 Available at:<https://cutt.ly/oeJMdhr>. Accessed: 19 January 2019.

BORD, R.J.; FISHER, A.; O'CONNOR, R.E. Public perceptions of global warming: United States and international perspectives. Climate Research, Oldendorf, v. 11, p. 75-84, 1998.

BOYKOFF, M. T.; ROBERTS, J. T. Media coverage of climate change: current trends, strengths, weaknesses. Human Development Report 2007/2008: report. New York, 2007. Available at: $<$ https://cutt.ly/NeG2Vfo>. Accessed: 19 January 2019.

BRECHIN, S. R. Comparative public opinion and knowledge on global climatic change and the Kyoto Protocol: the U.S. versus the world? International Journal of Sociology and Social Policy, Sheffield, v. 23, n. 10, p. 106-134, 2003.

BRULLE, R. J.; CARMICHAEL, J.; JENKINS, J. C. Shifting public opinion on climate change: an empirical assessment of factors influencing concern over climate change in the U.S., 20022010. Climatic Change, v. 114, n. 2, p. 169-188, 2012.

CERRILLO, A., Conclusiones. Una alianza entre pedagogía e información. In: . (Coord.). El periodismo ambiental: análisis de un cambio cultural en España. Barcelona: Fundación Gas Natural, 2008, p. 197-198.

DE RUEDA, Á. El discurso político y el tratamiento periodístico del cambio climático en la prensa española durante las Conferencias de las Partes de Naciones Unidas: de Copenhagen (2009) a Varsovia (2013). 2014. PhD in Social Communication - Faculty of Humanities and Social Communication, Universidad CEU Cardenal Herrera, Valencia, 2014. Available at: < https://cutt.ly/8eJZMtM>. Accessed: 3 February 2019.

DEL OLMO, J.; PARRATT, S. Typography and colour: A comparative analysis of the free and paid-for newspapers in Spain. Revista Latina de Comunicación Social, La Laguna, v. 66, p. 376 398, 2011. Available at: < https://cutt.ly/ZeJMiNA>. Accessed: 11 February 2019.

DÍAZ-NOSTY, B. Media and climate change: from content analysis to analysis content: approximation to the interdisciplinary construction of a new paradigm. In: XINXUN, W.; HAN, Z.; XIAOKUN, W. (Ed.). New Media and Transformation of Social Life in China. New Delhi: Sage, 2017. p. 125-146.

ERVITI, M. C. Las imágenes del cambio climático en los informativos de Televisión. Análisis de seis televisiones españolas de cobertura nacional. 2013. $\mathrm{PhD}$ in Communication - Faculty of Comunicación, University of Navarra, Pamplona, 2013. Available at: < https://cutt.ly/KeJX- 
pQz>. Accessed: 1 February 2019.

EUROPEAN COMMISSION. Special Eurobarometer 459 Climate Change. Report, European Commission: barómeter. 2017 (September). Available at: <https://cutt.ly/AeCa2vP > Accessed: 4 May 2019.

FERNÁNDEZ-REYES, R. La función formativa o educativa en el Periodismo Ambiental. Contribuciones a las Ciencias Sociales, March 2011. Available at: $<$ https://cutt.ly/oeCri4j $>$. Accessed: 4 February 2019.

FERNÁNDEZ-REYES, R. La comunicación del cambio climático en la prensa. Una mirada global en el contexto actual y evolución en los últimos años. In: Teso, G., Fernández-Reyes, R., Gaitán, J. A., Lozano, C. \& Piñuel, J. L. Comunicación para la sostenibilidad: el cambio climático en los medios: working paper. Madrid: Fundación Alternativas, 2018, p. 59-71. Available at:<http://cort.as/-Sj5r>. Accessed: 4 April 2019.

FERNÁNDEZ-REYES, R.; PIÑUEL, J. L.; VICENTE, M. Media coverage of climate change and global warming in El País, El Mundo and La Vanguardia. Revista Latina de Comunicación Social, La Laguna, v. 70, p. 122-140, 2015. Available at: < https://cutt.ly/beJMrPi>. Accessed: 29 January 2019.

FERNÁNDEZ-REYES, R.; PIÑUEL, J. L.; ÁGUILA, J. C. Contraste de la cobertura periodística del cambio climático y del calentamiento global en España y en el ámbito internacional: IV-V Informes del IPCC y Bali-Copenhague-París. Revista Latina de Comunicación Social, La Laguna, v. 72, p. 1.165-1.185, 2017. Available at: < https://cutt.ly/WeJN6ZL>. Accessed: 30 January 2019.

FUNDACIÓN BBVA. Percepciones y actitudes de los españoles hacia el calentamiento global: study. Madrid, 2008. Available at: <https://cutt.ly/weJCDNh>. Accessed: 11 April 2019.

HERAS, F. Comunicar el cambio climático. In: RIECHMANN, J. (Coord.) ¿En qué estamos fallando? Cambio social para ecologizar el mundo. Barcelona: Icaria, 2008. p. 201-238.

HERAS, F. ¿Cómo comunicar el cambio climático? San Sebastián: Observatorio de la Sostenibilidad. Fundación Cristina Enea, 2018. Available at: < https://cutt.ly/weJVfT0>. Accessed: 30 December 2018.

IPCC - INTERGOVERNMENTAL PANEL ON CLIMATE CHANGE. Global warming of $1.5^{\circ} \mathrm{C}$ : report. IPCC, 2018. Available at: < https://www.ipcc.ch/sr15/>. Accessed: 30 December 2018.

JACOBI, P. R.; DE ASSIS, M. R. Desafíos y estrategias para fortalecer las relaciones entre ciencia y política en relación al cambio climático. Ambiente $\mathbb{\&}$ Sociedade, Campinas, v. 19, n. 4, pp. 195-210, 2016. Available at: <https://cutt.ly/zeJNOQu>. Accessed: 30 December 2018.

KOLLMUSS, A.; AGYEMAN, J. Mind the Gap: Why do people act environmentally and what are the barriers to pro-environmental behavior? Environmental Education Research, Melbourne, v. 8, n. 3, p. 239-260, 2002. 
KUA, E.; REDER, M.; GROSSEL, M. J. Science in the News: A Study of Reporting Genomics. Public Understanding of Science, Berlin, v. 13, n. 3, p. 309-22, 2004.

LEE, T.; MARKOWITZ, E.; HOWE, P.; KO, C.; LEISEROWITZ, A. Predictors of public climate change awareness and risk perception around the world. Nature Clim Change, 5, p. 1014-1020, 2015.

LEÓN, B.; DE LARA, A. Ciencia y cambio climático. Estudio de la cobertura del cambio climático en la prensa española. In: Mancinas, R. (Coord.); Fernández, R. (Dir.), Medios de comunicación y cambio climático. Sevilla: Fénix, 2013. p. 91-104.

LOPERA, E.; MORENO, C. The uncertainties of climate change in Spanish daily newspapers: content analysis of press coverage from 2000 to 2010. Journal of Science Communication, Trieste, v. 13, n. 1, p. 1-18, 2014a. Available at: < https://cutt.ly/qeJNFfQ>. Accessed: 2 January 2019.

LOPERA, E.; MORENO, C. The iconographic discourse of climate science, examined through the press coverage of Spanish daily newspapers. In: 13TH INTERNATIONAL PUBLIC COMMUNICATION OF SCIENCE AND TECHNOLOGY CONFERENCE. Salvador de Bahía. Proceedings... Barcelona: PCST Network, 2014b. Available at:<http://cort.as/-Sj6Z>. Accessed: 9 January 2019.

LOZANO, C. El cambio climático en los telediarios: alusiones a la catástrofe en tiempos de calma. Anuario Electrónico de Estudios En Comunicación Social “Disertaciones”, Bogotá, v. 6, n. 1, p. 124-140, 2013. Available at:<https://cutt.ly/leJNPBk>. Accessed: 4 January 2019.

MASTERNMAN, L. La educación en materia de comunicación: problemas teóricos y posibilidades concretas. Perspectivas: revista trimestral de educación comparada, v. 13, n. 2, p. 183-191, 1993. Available at: https://cutt.ly/OeJNUMN. Accessed: 24 January 2019.

MEIRA, P. Á. La sociedad ante el cambio climático. Conocimientos, valoraciones y comportamientos en la sociedad. Madrid: Fundación Mapfre, 2009. Available at: https://n9.cl/q4mp. Accessed: 24 January 2019.

MEIRA, P. Á. Problemas ambientales globales y educación ambiental: Una aproximación desde las representaciones sociales del cambio climático. Revista Integra Educativa, La Paz, v. 6, n. 3, p. 29-64, 2013. Available at:<https://cutt.ly/teGMnKr>. Accessed: 24 January 2019.

MEIRA, P. Á. (Dir.); Arto, M.; Heras, F.; Iglesias, L.; Lorenzo, J. J.; Montero, P. La respuesta de la sociedad española ante el cambio climático. Madrid: Fundación Mapfre, 2013. Available at: https://n9.cl/5s6w. Accessed: 21 January 2019.

MENESES, M. D.; MARTÍN, J. ¿Tienen razón los investigadores al quejarse de la información periodística sobre ciencias? Experiencias con alumnos de Periodismo y científicos. Revista Española de Documentación Científica, Madrid, v. 38, n. 4, p. 1-14, 2015. Available at:<https:// n9.cl/t7zw>. Accessed: 23 December 2018.

NOGUERA, C. La representación del cambio climático en los medios. In: LEÓN, B. (Ed.). El 
periodismo ante el cambio climático. Nuevas perspectivas y retos. Barcelona: UOC, 2013. p. 45-70.

NORGAARD, K. M. Living in Denial: Climate Change, Emotions, and Everyday Life. Cambridge, MA: MIT Press, 2011.

OLAYIWOLA, A. Mass Media of Communication and Environmental Problems: Islamic Religious Communication Solutions Perspectives. Journal of Mass Communication and Journalism, Henderson, v. 5, n. 3, 1-7, 2015. Available at: <https:/cutt.ly/leGMChZ>. Accessed: 2 January 2019.

O'NEILL, S. J.; SMITH, N. Climate change and visual imagery: Climate change and visual imagery. WIREs Climate Change, Hoboken, v. 5, n. 1, p. 73-87, 2014.

O’NEILL, S.; NICHOLSON-COLE, S. "Fear Won't Do It": Promoting Positive Engagement With Climate Change Through Visual and Iconic Representations. Science Communication, v. 30, n. 3, p. 355-379, 2009.

PARRATT, S. Climate change in Spain's media: a deficient answer. Infoamérica: Iberoamerican Communication Review, Málaga, v. 1, p. 129-138, 2009.

PARRATT, S. El periodismo ambiental como especialidad en las universidades españolas. Prisma Social, Madrid, n. 12, June-November, p. 335-363, 2014. Available at: < https://cutt. ly/6xHVKbr>. Accessed: 15 April 2019.

PÉREZ, T.; PERALES, F. J. El cambio climático visto desde internet: una evaluación de su contenido y mensaje. Estudios sobre el Mensaje Periodístico, Madrid, v. 24, n. 2, p. 1507-1524, 2018. Available at:<https://n9.cl/uii5>. Accessed: 9 January 2019.

PEW RESEARCH CENTER. Climate Change Still Seen as the Top Global Threat, but Cyberattacks a Rising Concern. Report: report. Washington, 2019. Available at: < https://cutt.ly/ KeCgnm2>. Accessed: 14 April 2019.

POORTINGA et al. European Attitudes to Climate Change and Energy. Topline Results from Round 8 of the European Social Survey: report. London, 2018. Available at: <https:// cutt.ly/deCgO5c>. Accessed: 14 April 2019.

QUESADA, M.; BLANCO, E.; TERUEL, L. El cambio climático en la prensa europea: discurso editorial en El País, Le Monde, The Guardian y Frankfurter Allgemeine Zeitung. Estudios Sobre El Mensaje Periodístico, Madrid, v. 21, n. 1, p. 523-539, 2015. Available at: < https://n9.cl/ prjn >. Accessed: 11 January 2019.

RÖGENER, W., WORMER, H. Defining criteria for good environmental journalism and testing their applicability: An environmental news review as a first step to more evidence based environmental science reporting. Public Understanding of Science, Berlin, v. 26, n. 4, p. 418-433, 2017.

ROWAN, K. E. Informing and explaining skills: Theory and research on informative communication. In: GREEN, J. O.; BURLESON, B. R. (Ed.). Handbook of communication and social 
interaction skills. Mahwah, NJ, and London: Laurence Erlbaum, 2003. p. 403-438.

SMITH, N. W.; JOFFE, H. Climate change in the British press: The role of the visual. Journal of Risk Research, v. 12, n. 5, p. 647-633, 2009.

SMITH, K. E.; MAYER, A. A social trap for the climate? Collective action, trust and climate change risk perception in 35 countries. Global Environmental Change, v. 49, p. 140-153, 2018. Available at: < https://n9.cl/kt07i>. Accessed: 10 March 2019.

TESO, G. et al. Comunicación para la sostenibilidad: el cambio climático en los medios: documento de trabajo. Madrid, 2018. Available at:<http://cort.as/-Sj5r > . Accessed: 19 April 2019.

VALENCIA, Á; ARIAS, M.; VÁZQUEZ, R. Opiniones y Actitudes no 67. Ciudadanía y conciencia medioambiental en España: informe. Madrid, 2010.

Available at: <https://n9.cl/5nth>. Accessed: 29 May 2019. 
Sonia Parratt Fernández

$\square$ sfparratt@ccinf.ucm.es

ORCiD: https://orcid.org/0000-0001-8501-3115
Submitted on: 22/01/2020

Accepted on: 02/02/2021

2021;24e:0186

\section{Montse Mera Fernández}

$\checkmark$ mmera@ucm.es

ORCiD: https://orcid.org/0000-0003-4702-9786

\section{Paloma Abejón Mendoza}

$\checkmark$ pabejonm@ucm.es

ORCiD: https://orcid.org/0000-0001-9960-5154

How to cite: PARRATT, S.; MERA, M.; ABEJÓN, P. Approaching climate change to society from the media: formative elements in Spanish digital newspapers. Ambiente $\mathbb{E}$ Sociedade. São Paulo, v. 24, p. 1-17, 2021. 


\title{
Aproximação da mudança climática à sociedade pela mídia: elementos formativos na imprensa digital espanhola
}

\author{
Sonia Parratt Fernández \\ Montse Mera Fernández \\ Paloma Abejón Mendoza
}

São Paulo. Vol. 24, 2021

Artigo Original
Resumo: Com base na responsabilidade dos meios de comunicação em matéria ambiental, este estudo põe o foco num novo aspecto na investigação sobre a cobertura mediática da mudança climática: a presença de elementos que contribuiriam para a dar a conhecer e compreender este fenómeno, e a orientar aos leitores sobre como atuar individualmente frente a ele. $\mathrm{O}$ método utilizado foi a análise de conteúdo quantitativa das edições digitais dos jornais espanhóis de informação geral a nível nacional com maior difusão em 2017. Os resultados sugerem que os jornais apenas incluem explicações simples da mudança climática; contextualizam o problema abordando as suas causas e efeitos mas estes continuam a ter primazia; oferecem muito poucas orientações aos cidadãos para o combater; e fazem um uso limitado de recursos visuais. Estes dados forneçam um interessante ponto de partida para, em trabalhos futuros, avaliar a eficácia dos elementos formativos para promover a implicação dos leitores.

Palavras-chave: Mudança climática; mídia; jornalismo ambiental; educação ambiental; elementos formativos; Espanha

Como citar: PARRATT, S.; MERA, M.; ABEJÖN, P. Aproximação da mudança climática à sociedade pela mídia: elementos formativos na imprensa digital espanhola. Ambiente $\&$ Sociedade. São Paulo, v. 24, p. 1-20, 2021. 


\title{
Acercamiento mediático del cambio climático a la sociedad: elementos formativos en diarios digitales españoles
}

\author{
Sonia Parratt Fernández \\ Montse Mera Fernández \\ Paloma Abejón Mendoza
}

São Paulo. Vol. 24, 2021

Artículo original
Resumen: Partiendo de la responsabilidad de los medios de comunicación en materia ambiental, este estudio pone el foco en un nuevo aspecto en la investigación de la cobertura mediática del cambio climático: la presencia de elementos formativos, aquellos que contribuirían a dar a conocer y comprender este fenómeno, y a orientar al lector sobre cómo actuar individualmente frente a él. El método utilizado es el análisis de contenido cuantitativo de las ediciones digitales de los periódicos generalistas españoles de ámbito nacional con mayor difusión durante 2017. Los resultados sugieren que estos diarios apenas incluyen explicaciones sencillas; contextualizan el problema abordando sus causas y efectos pero siguen primando estos últimos; aportan muy pocas recomendaciones al ciudadano para combatirlo; y hacen un uso limitado de recursos visuales. Estos datos constituyen un interesante punto de partida para, en futuros trabajos, determinar la eficacia de estos elementos para fomentar la implicación de los lectores.

Palabras-clave: Cambio climático; medios de comunicación; periodismo ambiental; educación ambiental; elementos formativos; prensa; España

Como citar: PARRATT, S.; MERA, M.; ABEJÓN, P. Acercamiento mediático del cambio climático a la sociedad: elementos formativos en diarios digitales españoles. Ambiente $\mathbb{\&}$ Sociedade. São Paulo, v. 24, p. 1-20, 2021. 